\title{
Bartosz Wachnik
}

Politechnika Warszawska

e-mail: bartek@wachnik.eu

\section{ANALIZA KOSZTÓW TRANSAKCYJNYCH W INFORMATYCZNYCH PRZEDSIĘWZIĘCIACH WDROŻENIOWYCH REALIZOWANYCH POPRZEZ OUTSOURCING}

\section{THE ANALYSIS OF TRANSACTION COSTS IN IT IMPLEMENTATION PROJECTS WITH THE USE OF OUTSOURCING}

DOI: 10.15611/ie.2015.1.06

\begin{abstract}
Streszczenie: Wdrażanie systemów informatycznych wspierających zarządzanie, wykorzystując outsourcing, jest najbardziej popularnym sposobem realizacji projektów w Polsce. Teoria kosztów transakcyjnych stanowi istotną składową nowej ekonomii instytucjonalnej, która w znaczący sposób objaśnia m.in. relacje biznesowe między dostawcami a odbiorcami w ramach outsourcingu. Celem niniejszego artykułu jest przedstawienie rezultatów badań dotyczących teorii kosztów transakcyjnych analizowanych wśród informatycznych przedsięwzięć wdrożeniowych, polegających na wdrożeniu standardowych systemów wspierających zarządzanie klasy ERP, CRM, DMS, BI wśród przedsiębiorstw w Polsce w ramach outsourcingu. Autor w artykule przedstawia perspektywę zarówno klienta, jak i dostawcy. Rezultaty badań mogą być interesujące dla teoretyków informatyki gospodarczej i praktyków organizujących przedsięwzięcia informatyczne w przedsiębiorstwach i w agendach rządowych wykorzystujących koncepcje outsourcingu.
\end{abstract}

Słowa kluczowe: teoria, koszty transakcyjne, MIS, outsourcing.

Summary: The theory of transaction costs constitutes an important component of the new institutional economy, which, amongst others, explains to a great extent business relations between the suppliers and the clients as part of outsourcing. The aim of this article is to present the results of research concerning the transaction cost theory analysed on the example of IT implementation projects consisting in the implementation of standard ERP, CRM, DMS and BI-class management support systems amongst enterprises based in Poland as part of outsourcing. The article presents both the client's and the supplier's perspective. The research results can be interesting for theorists of business informatics and for practitioners implementing IT projects both in enterprises and government agencies with the use of outsourcing.

Keywords: theory, transaction costs, MIS, outsourcing. 


\section{Wstęp}

Zjawiska zachodzące we współczesnej gospodarce światowej, takie jak: zmiany koniunktury, dynamicznie pojawiające się czynniki ryzyka realizacji przedsięwzięć o wysokim stopniu skomplikowania technologicznego, rozwój technologii informacyjno-komunikacyjnych (ICT), wspierających wymianę informacji między przedsiębiorstwami, powodują że zarządzający powinni być świadomi współdziałania $\mathrm{z}$ innymi, często niezależnymi podmiotami $\mathrm{w}$ ramach outsourcingu. Na szczególną uwagę zasługują przedsięwzięcia informatyczne oraz ich sposób realizacji opierający się na outsourcingu, biorąc pod uwagę poziom skuteczności ich realizacji. Według przedstawionych w tab. 1 wyników badań przeprowadzonych przez autora w latach 2010-2014 wśród przedsięwzięć informatycznych ${ }^{1}$ zrealizowanych w Polsce średni współczynnik sukcesu wynosi $61 \%$, co oznacza, że średnio $39 \%$ przedsięwzięć informatycznych kończy się niepowodzeniem całkowitym lub częściowym. Na uwagę zasługuje to, że średni współczynnik niepowodzenia całkowitego wynosił jedynie 19\%. Pogłębione badania prowadzone przez autora wskazały, że średni poziom przedsięwzięć zakończonych sukcesem wśród przedsiębiorstw o kapitale zagranicznym wynosił $62 \%$, a wśród przedsiębiorstw o kapitale krajowym - 38\%. Więcej jest zatem przedsięwzięć zakończonych sukcesem w firmach zagranicznych. Interesujące jest także to, że większy odsetek przedsięwzięć zakończonych niepowodzeniem całkowitym można odnotować we wdrożeniach realizowanych w przedsiębiorstwach zagranicznych (64\%) niż w przedsiębiorstwach o kapitale polskim (36\%). Odwrotnie jest w odniesieniu do przedsięwzięć zakończonych niepowodzeniem częściowym - większy odsetek tych przedsięwzięć jest wśród przedsiębiorstw o kapitale polskim (71\%) niż wśród przedsiębiorstw o kapitale zagranicznym (29\%).

Celem niniejszego artykułu jest przedstawienie rezultatów badań dotyczących występowania kosztów transakcyjnych w trakcie realizacji projektów informatycznych polegających na wdrożeniu systemów informatycznych wspierających zarządzanie, tj. ERP, BI, CRM, DMS, wykorzystując outsourcing. Przeprowadzenie badań oraz opracowanie i interpretacja wniosków miały respektować dwa główne postulaty: dostatecznej ogólności, aby była możliwość wyciągnięcia wniosków dla szerszej grupy zainteresowanych oraz aplikacyjności, aby wyniki służyły skuteczniejszej realizacji projektów informatycznych. Genezą tego artykułu jest próba szerszego zidentyfikowania uwarunkowań wpływających na skuteczność realizacji wybranej

\footnotetext{
${ }^{1}$ Badania dotyczyły 450 projektów informatycznych zrealizowanych w trybie outsourcingu w 425 firmach zlokalizowanych na Mazowszu, w Wielkopolsce i Małopolsce oraz na Górnym i Dolnym Śląsku w latach 2010-2014, które w tym okresie zrealizowały projekty polegające na wdrożeniu systemów informatycznych wspomagających zarządzanie. Przedsiębiorstwa zaklasyfikowane do badania spełniały następujące kryteria: liczba zatrudnionych - od 80 do 1000 pracowników, firma ma własny dział informatyki, minimalny przychód - $40 \mathrm{mln}$ zł. Średni budżet projektu uwzględniający jedynie usługi wynosił 478 tys. zł. W analizowanych projektach brano pod uwagę wdrożenie systemów informatycznych klas: ERP, CRM, BI, DMS, e-learning.
} 
Tabela 1. Rozkład skuteczności realizacji przedsięwzięć informatycznych

\begin{tabular}{|l|c|c|c|c|c|}
\hline \multicolumn{1}{|c|}{ Przedsięwzięcie informatyczne } & 2010 & 2011 & 2012 & 2013 & 2014 \\
\hline $\begin{array}{l}\text { Przedsięwzięcia zakończone } \\
\text { sukcesem (projekty zakończone } \\
\text { w budżecie finansowym, na czas, } \\
\text { wdrożone wszystkie wymagane } \\
\text { funkcjonalności) }\end{array}$ & $56 \%$ & $59 \%$ & $63 \%$ & $64 \%$ & $64 \%$ \\
\hline $\begin{array}{l}\text { Przedsięwzięcia zakończone porażką } \\
\text { projekty wstrzymane i nigdy } \\
\text { niedokończone) }\end{array}$ & $21 \%$ & $19 \%$ & $22 \%$ & $17 \%$ & $16 \%$ \\
\hline $\begin{array}{l}\text { Przedsięwzięcia z problemami } \\
\text { projekty zakończone z opóźnieniem, } \\
\text { z przekroczonym budżetem, } \\
\text { wdrożone nie wszystkie wymagane } \\
\text { funkcjonalności) }\end{array}$ & $23 \%$ & $22 \%$ & $15 \%$ & $19 \%$ & $20 \%$ \\
\hline
\end{tabular}

Źródło: opracowanie własne.

grupy projektów informatycznej opierającej się na outsourcingu. Niniejszy artykuł jest rezultatem badań naukowych autora prowadzonych w ostatnich dwóch latach. Badania dotyczyły realizacji informatycznych przedsięwzięć wdrożeniowych w ramach outsourcingu; tę problematykę analizowano z perspektywy zarówno dostawcy, jak i klienta [Wachnik 2015; 2014].

\section{Teoria kosztów transakcyjnych}

Według S. Gregora [Gregor 2006, s. 611-642] można wyróżnić pięć typów teorii wykorzystywanych rozwoju informatyki ekonomicznej, tj.

1. Teorie analityczne. Opisują badania zjawiska lub rzeczy, koncentrując się na wydzieleniu elementów składowych, cech oraz wewnętrznej struktury. Nie próbują zidentyfikować wzajemnego wpływu, związków przyczynowo-skutkowych ani określić prognozy przyszłego kształtu. Teorie takie są nazywane również klasyfikacją, typologią, taksonomią lub systematyką.

2. Teorię wyjaśniające. Zajmują się odpowiedziami na pytania: jak, dlaczego, kiedy i gdzie określone zjawiska zachodzą.

3. Teorie prognostyczne. Opisują trendy i stawiają weryfikowalne hipotezy umożliwiające prognozowanie zjawisk. Nie zajmują się jednak aksjologicznymi aspektami czy też nie próbują wyjaśniać zachodzących zjawisk.

4. Teorie prognostyczno-wyjaśniające. Są połączeniem teorii prognostycznych $\mathrm{z}$ interpretacją i wyjaśnieniem badanych zjawisk.

5. Teorie receptur. Zajmują się odpowiedzią na pytanie, jak coś wykonać. S. Gregor nazywa je teoriami projektów i działań. 
$\mathrm{Na}$ świecie zagadnienia związane z outsourcingiem informatycznym są przedmiotem badań teoretyków informatyki gospodarczej od wielu lat. J. Dibbern [Dibbern i in. 2004, s. 6-102] przeanalizował 84 artykuły opublikowane w okresie 1992-2000, dotyczące outsourcingu informatycznego [Auksztol 2008, s. 44]. Zidentyfikowano 10 kategorii teorii wykorzystywanych przy analizie tematyki outsourcingu informatycznego. Kategoria teorii kosztów transakcyjnych, należąca do typu teorii wyjaśniających, znalazła się na pierwszym miejscu pod względem liczby publikacji ${ }^{2}$, co pokazuje, iż była najczęściej wykorzystywana do badań nad outsourcingiem informatycznym. Twórcą aktualnej teorii kosztów transakcyjnych jest O.E. Williamson [Williamson 1979, s. 233-261], natomiast jej podstawy koncepcyjne przedstawił R.H. Coase [Coase 1937, s. 386-405] w swej klasycznej publikacji o cechach charakterystycznych przedsiębiorstwa. Według autora niniejszej publikacji interesującą definicję kosztów, wynikającą z analizowanego przez niego obszaru badawczego przedstawił J.A. Robins [Robins 1987, s. 69] - koszty związane z ekonomiczną wymianą, które zmieniają się niezależnie od cen rynkowych wymienianych dóbr i usług. Obejmują one koszty poszukiwań i informacji oraz koszty monitorowania i zagwarantowania należytego wykonania umowy. Koszty te są przeciwstawiane kosztom produkcji, stanowiącym podstawę analizy w ramach ekonomicznych teorii neoklasycznych, w tym również alokacji zasobów [Auksztol 2008, s. 44]. Pojawienie się pojęcia kosztów transakcyjnych wynikało z pominięcia istotnego zakresu działalności każdej organizacji, wykraczającego poza funkcje produkcji, a wpływającego w istotny sposób na decyzje wyboru form organizacyjnych. Należy w tym miejscu podkreślić, iż orędownicy tej teorii nie precyzują zamkniętej listy takich kosztów. Klasyfikują je jednak według podziału zaproponowanego przez Williamsona [Williamson 1979, s. 233-261] na rynek i hierarchię [Auksztol 2008, s. 44]:

1. Rynek stanowi miejsce wymiany dóbr i usług, gdzie cena, tj. wartość wymiany, jest uregulowana przez siły popytu i podaży. Teoria kosztów transakcyjnych podaje następujące przykłady kosztów:

a. Koszty asymetrii informacji - decyzje o zawieraniu kontraktów są podejmowane w sytuacji, kiedy wiedza o przedmiocie obrotu handlowego nie jest równomiernie rozłożona; strony kontraktu nie mają dostępu do takiego samego zasobu informacji, a to powoduje, że w trakcie realizacji porozumienia koniecznie staje się dopasowanie kontraktu do nowych warunków powstałych po uzyskaniu dodatkowej wiedzy na temat przedmiotu zamówienia: proces ten jest związany z ponoszeniem tzw. kosztów asymetrii informacji.

\footnotetext{
${ }^{2}$ Ranking wykorzystywanych teorii przy badaniu outsourcingu informatycznego z wykorzystaniem 84 artykułów, opracowany w [Dibbern i in. 2004, s. 6-102], podaje następującą kolejność: teoria kosztów transakcyjnych -16 , teoria zarządzania strategicznego - 14, teoria agencji - 10, grupa teorii alokacji zasobów -9 , grupa teorii wymiany społecznej -7 , teoria gier -4 , grupa teorii władzy -2 , teoria dyfuzji innowacji -2 , teorie pozostałe, np.: zarządzanie wiedzą, zarządzanie ryzykiem, kontraktu psychologicznego - 13 .
} 
b. Koszty zawierania umowy - każda umowa na dostawę oraz świadczenie usług wymaga jej fachowego przygotowania, z czym wiążą się określone koszty pomijane przez wielu teoretyków i praktyków nauk o zarządzaniu: są to opracowania jednoznacznego przedmiotu umowy, pozyskania informacji o kontrahentach, dokonania wyboru, a wyjątkowych przypadkach przeprowadzenia procesu przetargowego, przygotowania treści umowy, przeprowadzenie negocjacji oraz ustalenia i zabezpieczeń należytego wykonania umowy [Miranda, Kim 2006, s. 725-753].

c. Koszty nadzoru realizacji umowy - wykorzystywanie mechanizmów rynkowych nie zwalnia odbiorcy $\mathrm{z}$ obowiązku monitorowania oraz ceny rezultatów i cząstkowych kontraktu: koszty z tym związane mieszczą się w grupie kontroli i nadzoru nad wykonywaniem przedmiotu umowy.

d. Koszty dopasowania umowy do zmieniających się warunków: w wyniku splotu czynników społecznych (oportunizmu i ograniczonej racjonalności) oraz transakcyjnych (specyfika aktywów i niepewność) pojawiają się rozbieżności w ocenie rezultatów kontaktu: to powoduje konieczność przeprowadzenia działań dopasowujących, wymuszających ponoszenie kosztów: poprzez zawieranie kontraktów długoterminowych podejmowane jest ryzyko niedopasowania zapisów umowy do zdarzeń przyszłych: im większa dynamika otoczenia oraz specyfika przedmiotu umowy, w tym większe koszty dopasowania do nieprzewidzianych zdarzeń.

e. Koszty zakończenia umowy, w tym koszty zerwania kontraktu, nazywane ukrytymi, co świadczy o braku świadomości ich znaczenia; odnoszą się do dwóch przypadków: z jednej strony przy poprawnym zakończeniu relacji outsourcingowej należy podjąć działania umożliwiające dalsze wykonywanie usług, np.: udostępnienie know-how na potrzeby ponownego przeniesienia zasobów informacyjnych do zleceniodawcy lub do innego podmiotu świadczącego te same usługi; z drugiej strony konieczna jest identyfikacja zagrożeń niewykonania umowy, a w konsekwencji jej zerwania i ponoszenia kosztów z tym związanych.

2. Hierarchia jest organizacyjną formą realizacji działań, a zależności między jej elementami są ustalone przez podległość służbową lub przez stosunki własności. Teoria kosztów transakcyjnych nie porusza jednak tematyki związanej z ponoszeniem kosztów funkcjonowania struktur hierarchicznych, pozostawiając ją teorii agencji. Ma ona na celu wyjaśnienie przyczyn powstawania przedsiębiorstwa, traktowanego jako hierarchia, w opozycji do mechanizmów rynkowych. Skoncentrowano się więc na identyfikowaniu zaburzeń działania rynku, zmniejszających efektywność jego funkcjonowania. Zaburzenia utożsamiano z kosztami transakcyjnymi, które - według tej teorii - mogłyby być zmniejszone bądź też wyeliminowane przez przeniesienie funkcji produkcyjnych z rynku do hierarchii. 


\section{Relacje między dostawcami i odbiorcami kontraktów outsourcingowych projektów informatycznych w świetle teorii kosztów transakcyjnych}

Według J. Lee [Lee, Miranda, Kim 2004, s. 110-131] outsourcing informatyczny to zarządzanie firmową infrastrukturą informatyczną poprzez mechanizmy administracyjne wykonywane w kooperacji z zewnętrznymi organizacjami. Biorąc pod uwage koncepcje całkowitego kosztu posiadania systemu informatycznego, $\mathrm{tj}$. TCO, można stwierdzić, że analiza kosztów transakcyjnych powinna się odbywać w całym cyklu projektu, tj. w ramach trzech wyróżnionych etapów; są nimi:

1. Organizacja i realizacja przetargu mającego na celu wybór systemu informatycznego wspomagającego zarządzanie oraz firmy wdrażającej.

2. Realizacja przedsięwzięcia informatycznego.

3. Eksploatacja systemu informatycznego na podstawie umowy Service Level Agreement

W każdym z nich zarówno klient, jak i dostawca powinni być przygotowani do realizacji wspólnego projektu, rozumiejąc i akceptując szacowany wcześniej i znany dwóm stronom poziom kosztów transakcyjnych. Niestety, wiele organizacji, inwestując w system informatyczny, nie bierze w sposób racjonalny pod uwage mogących się pojawić kosztów transakcyjnych, które powinny być szacowane ex ante na etapie planowania inwestycji, czyli w etapie 1 . Według autora przekroczenie akceptowalnego poziomu kosztów transakcyjnych w trakcie etapów 2 oraz 3 może być jednym ze źródeł turbulencji organizacyjnych projektu, którymi mogą być przekroczenie budżetu finansowego, przekroczenie terminu realizacji projektu w etapie 2, brak możliwości uzyskania planowanych celów biznesowych stawianych przed projektem lub jego zakończenie porażką na skutek odstąpienia od jego dalszego wdrożenia. Mimo że badania dotyczące kosztów transakcyjnych w przedsięwzięciach informatycznych w ostatnich latach prowadzone są intensywnie, w literaturze fachowej, w szczególności polskiej, występuje luka, jeśli chodzi o kwestię analizy uwarunkowań kosztów transakcyjnych, głównie informatycznych przedsięwzięć wdrożeniowych, polegających na wdrożeniu systemów klasy ERP, CRM, BI, DMS.

\section{Metodyka badań}

Wybór tematyki badania wynikał z przeświadczenia, iż skuteczność realizacji projektów informatycznych, zwłaszcza w Polsce, może być uzależniona nie tylko od wykorzystywanych metod i technik zarządzania projektem, ale również od czynników wynikających ze struktury kosztów transakcyjnych w każdym z trzech etapów cyklu życia projektu. Głównym problemem badawczym stawianym w publikacji jest próba identyfikacji czynników wpływających na koszty transakcyjne projektu, których wysokość może być istotną przyczyną turbulencji organizacyjnych projek- 
tu. Zrozumienie poglądów i map poznawczych dotyczących ponoszonych kosztów transakcyjnych ma istotne znaczenie dla opisu dominującej logiki działania outsourcingu w zakresie realizacji projektów informatycznych wspierających zarządzanie wśród dużej grupy przedsiębiorstw w Polsce. Badania prowadzono w następujących etapach projektowo-badawczych.

1. Analiza literaturowa.

2. Badania ankietowe.

3. Pogłębione analizy warsztatowe wśród wybranych przedsiębiorstw.

Wykorzystanie trzech metod badawczych, tj. metody studiów literaturowych, ankietowej i analizy pogłębionych warsztatów, było podyktowane chęcią triangulacji danych oraz weryfikacji wniosków jednostkowych w kolejnych projektach. Głównym zagadnieniem badawczym, które autor chciałby wyjaśnić, korzystając $\mathrm{z}$ teorii kosztów transakcyjnych, jest identyfikacja kosztów transakcyjnych w poszczególnych etapach cyklu życia projektu w przedsiębiorstwach już mających wdrożone systemy informatyczne wspierające zarządzanie w Polsce, zarówno po stronie dostawcy, jak i odbiorcy. W badaniach dążono do identyfikacji głównych czynników wpływających na zwiększenie kosztów transakcyjnych wśród wybranej grupy przedsiębiorstw w Polsce, które zakończyły realizację etapów 1, 2 i które realizują etap 3. Rezultaty badań będą stanowić podstawę do dalszych pogłębionych badań wykorzystujących analizy statystyczne metodą regresji oraz równań strukturalnych. Badania ankietowe zostały przeprowadzone w ujęciu międzyregionalnym, z dominacją firm zlokalizowanych na Mazowszu oraz na Dolnym i Górnym Śląsku. Ankiety zebrano wśród 350 przedsiębiorstw, które przedstawiły odpowiedzi na pytania dotyczące 420 zrealizowanych przedsięwzięć informatycznych w okresie 2011-2015 polegających na wdrożeniu wspierających zarządzanie systemów informatycznych klasy ERP, BI, CRM, DMS. Wśród badanych firm było 49 dostawców oraz 301 odbiorców usług outsourcingowych. Z 420 analizowanych projektów 90 analizowano z perspektywy dostawcy, a 330 - z perspektywy odbiorcy. Dobrane firmy osiągały dobre lub przeciętne rezultaty w swoich branżach - nie były więc ani liderami, ani firmami peryferyjnymi. Grupa przedsiębiorstw reprezentująca klientów składała się z przedsiębiorstw następujących branż: spożywcza - 28\%, maszynowa $-17 \%$, farmaceutyczna $-14 \%$, motoryzacyjna $-4 \%$, meblarska $-30 \%$, tekstylna $-7 \%$. Celem badań było dotarcie do osób pośrednio lub bezpośrednio zaangażowanych w realizację przedsięwzięć informatycznych wspierających zarządzanie. Respondentami byli właściciele firm, prezesi, członkowie zarządu, dyrektorzy finansowi lub dyrektorzy IT. Po przeprowadzeniu badań ankietowych autor wykonał pogłębione analizy mające formę warsztatów, tj. spotkań z wybranymi reprezentantami firm, w celu weryfikacji odpowiedzi i przeprowadzenia dodatkowych wywiadów. 


\section{Rezultaty badań}

W tabeli 2 przedstawiono rezultaty badań. Efektem badań ankietowych jest pogrupowanie i priorytetyzacja kosztów transakcyjnych w odniesieniu do każdego etapu cyklu życia projektu.

Tabela 2. Struktura kosztów transakcyjnych w całym cyklu życia projektu wdrożenia i eksploatacji systemów informatycznych wspierających zarządzanie

\begin{tabular}{|c|c|c|c|}
\hline $\begin{array}{c}\text { Koszty } \\
\text { transakcyjne }\end{array}$ & $\begin{array}{l}\text { Etap w cyklu } \\
\text { życia projektu }\end{array}$ & Klient & Dostawca \\
\hline 1 & 2 & 3 & 4 \\
\hline $\begin{array}{l}\text { Koszty asymetrii } \\
\text { informacji. }\end{array}$ & Etap 1, 2, 3 & $\begin{array}{l}\text { 1. Koszty dodatkowe związane } \\
\text { z realizacją etapu } 2 \\
\text { projektu nie uwzględnione } \\
\text { w pierwotnej ofercie } \\
\text { dostawcy, które pozwalały } \\
\text { określić całkowite koszty } \\
\text { utrzymania aplikacji - } 76 \% \text {. } \\
\text { 2. Koszty dodatkowe związane } \\
\text { z realizacją etapu 3, tj. } \\
\text { umowy SLA - 67\%. } \\
\text { 3. Koszty związane } \\
\text { z ewentualną zmianą } \\
\text { polityki cenowej producenta } \\
\text { oprogramowania - 54\%. } \\
\text { 4. Koszty zmniejszenia } \\
\text { poziomu asymetrii } \\
\text { informacji między dostawcą } \\
\text { a odbiorcą poprzez } \\
\text { angażowanie zewnętrznego } \\
\text { eksperta - 49\%. }\end{array}$ & $\begin{array}{l}\text { 1. Koszty związane } \\
\text { z identyfikacją wymagań } \\
\text { funkcjonalnych klienta } \\
\text { wobec systemu, m.in. } \\
\text { poprzez spotkania } \\
\text { konsultantów } \\
\text { z kluczowymi } \\
\text { użytkownikami, zwłaszcza } \\
\text { gdy klient nie umiał lub } \\
\text { nie chciał poświęcić } \\
\text { odpowiednio dużo czasu, } \\
\text { aby wyrazić swoje } \\
\text { potrzeby wobec systemu - } \\
\text { 82\%. } \\
\text { 2. Koszty zmniejszenia } \\
\text { poziomu asymetrii } \\
\text { informacji między } \\
\text { dostawcą a odbiorcą } \\
\text { poprzez angażowanie } \\
\text { zewnętrznego eksperta - } \\
65 \% \text {. }\end{array}$ \\
\hline \begin{tabular}{|l} 
Koszty \\
zawierania \\
umowy
\end{tabular} & Etap 1 & $\begin{array}{l}\text { 1. Koszty identyfikacji } \\
\text { potrzeb funkcjonalnych } \\
\text { wobec systemu oraz } \\
\text { zorganizowania projektu } \\
\text { organizacyjnego - } 87 \% \text {. } \\
\text { 2. Koszty organizacji przetargu } \\
-81 \% \text {. } \\
\text { 3. Koszty opracowania } \\
\text { i uzgodnienia umowy dla } \\
\text { etapów } 2 \text { i } 3 \text { - zwłaszcza } \\
\text { gdy jedna ze stron dążyła } \\
\text { do umowy o charakterze } \\
\text { kazuistycznej - } 79 \% \text {. }\end{array}$ & $\begin{array}{l}\text { 1. Koszty obsługi procesu } \\
\text { sprzedaży projektu - } 92 \% \text {. } \\
\text { 2. Koszty opracowania } \\
\text { i uzgodnienia umowy } \\
\text { dla etapów } 2 \text { oraz } 3 \text { - } \\
\text { zwłaszcza gdy jedna ze } \\
\text { stron dażyła do umowy } \\
\text { o charakterze kazuistycznej } \\
\text { - } 91 \% \text {. }\end{array}$ \\
\hline
\end{tabular}


Tabela 2, cd.

\begin{tabular}{|c|c|c|c|}
\hline 1 & 2 & 3 & 4 \\
\hline $\begin{array}{l}\text { Koszty nadzoru } \\
\text { realizacji umowy }\end{array}$ & Etapy 2, 3 & $\begin{array}{l}\text { 1. Koszty zarządzania } \\
\text { projektem - } 91 \% \\
\text { 2. Koszty weryfikacji } \\
\text { rezultatów wybranych } \\
\text { zadań, które zostały } \\
\text { zrealizowane }-81 \% \\
\text { 3. Koszty stałej analizy czy } \\
\text { występuje hazard moralny } \\
\text { w zachowaniu drugiej strony } \\
-72 \%\end{array}$ & $\begin{array}{l}\text { 1. Koszty zarządzania } \\
\text { projektem - } 98 \% \\
\text { 2. Koszty uzyskania } \\
\text { weryfikacji rezultatów } \\
\text { wybranych zadan }-82 \% \\
\text { 3. Koszty stałej analizy czy } \\
\text { występuje hazard moralny } \\
\text { w zachowaniu drugiej } \\
\text { strony }-75 \%\end{array}$ \\
\hline $\begin{array}{l}\text { Koszty } \\
\text { dopasowania } \\
\text { umowy do } \\
\text { zmieniających się } \\
\text { warunków }\end{array}$ & Etapy 2, 3 & $\begin{array}{l}\text { 1. Koszty negocjacji } \\
\text { i opracowania nowej umowy } \\
\text { outsourcingowej dla etapu } \\
2 \text { lub 3, gdyby pojawiła } \\
\text { się potrzeba rozszerzenia } \\
\text { zakresu prac - 69\%. } \\
\text { 2. Koszty związane z obsługą } \\
\text { zarządzania zmianami, np. } \\
\text { założeń funkcjonalnych } \\
\text { uzgodnionych na etapie } \\
\text { analizy funkcjonalnej, } \\
\text { zmian osobowych w grupie } \\
\text { projektowej w etapach } 2 \text { i } 3 \\
\text { - 61\% } \\
\text { 3. Koszty związane } \\
\text { z obniżeniem wpływu } \\
\text { pojawiających się } \\
\text { dynamicznie w trakcie } \\
\text { realizacji etapu } 2 \text { oraz } 3 \\
\text { projektu czynników ryzyka } \\
\text { - 57\%. }\end{array}$ & $\begin{array}{l}\text { 1. Koszty związane z obsługą } \\
\text { zarządzania zmianami } \\
\text { w etapie } 2 \text { lub } 3-87 \% \text {. } \\
\text { 2. Koszty związane } \\
\text { z obniżeniem wpływu } \\
\text { czynników ryzyka } \\
\text { pojawiających się } \\
\text { dynamicznie w trakcie } \\
\text { realizacji etapów } 2 \\
\text { i } 3-77 \% \text {. }\end{array}$ \\
\hline $\begin{array}{l}\text { Koszty } \\
\text { zakończenia } \\
\text { umowy. }\end{array}$ & Etapy 2, 3 & $\begin{array}{l}\text { 1. Koszty związane } \\
\text { z nakładami pracy } \\
\text { związanymi z odbiorem } \\
\text { rezultatów końcowych } \\
\text { lub cząstkowych prac } \\
\text { projektowych na etapach } 2 \\
\text { i } 3-81 \% \text {. } \\
\text { 2. Koszty związane z re- } \\
\text { implementacją etapu } 2 \text { - } \\
79 \% \text {. } \\
\text { 3. Koszty procesowe } \\
\text { w przypadku skierowania } \\
\text { sprawy do sądu - 20\%. }\end{array}$ & $\begin{array}{l}\text { 1. Koszty związane } \\
\text { z poniesionymi } \\
\text { karami wynikającymi } \\
\text { z niezrealizowania projektu } \\
\text { w sposób właściwy - } 98 \% \text {. } \\
\text { 2. Koszty wynikające } \\
\text { z pojawienia się na rynku } \\
\text { informacji, że dostawca } \\
\text { nie zrealizował projektu } \\
\text { w sposób właściwy - 93\%. } \\
\text { 3. Koszty uzyskania finalnej } \\
\text { weryfikacji rezultatów } \\
\text { projektu - } 82 \% \text {. }\end{array}$ \\
\hline
\end{tabular}

Źródło: opracowanie własne. 
Z perspektywy klienta główne koszty transakcyjne związane $\mathrm{z}$ asymetrią informacji wynikały z dodatkowych kosztów związanych z realizacją projektu na etapie zarówno 2, jak i 3, które nie zostały zidentyfikowane w trakcie wdrażania etapu 1. Klienci wskazywali, iż wynikało to z dwóch przyczyn: braku umiejętności reprezentantów klientów identyfikacji potrzeb funkcjonalnych wobec budowanego systemu na etapie 1 oraz przekazywania przez dostawców bardzo ogólnych metainformacji dotyczących zarówno funkcjonalności systemu, jak również jego organizacji, które nie pozwalały precyzyjnie ocenić związanych z realizacją etapów 2 i 3 kosztów ponoszonych w przyszłości. Z perspektywy dostawcy najważniejsze koszty transakcyjne związane $\mathrm{z}$ asymetrią informacji wynikały z zachowań klienta, który albo nie umiał przekazać swoich wymagań funkcjonalnych $\mathrm{w}$ odniesieniu do budowanego systemu, albo nie chciał poświęcić odpowiednio dużo czasu, by wspólnie z konsultantami dostawcy opracować precyzyjne wymagania wobec systemu. Na uwagę zasługuje wskazanie zarówno przez dostawców, jak i przez odbiorców możliwości zaangażowania zewnętrznego eksperta jako trzeciej strony. Miałby on pełnić funkcję adwokata klienta w całym cyklu życia projektu. Warsztaty analityczne wskazały, iż koszt zaangażowania zewnętrznego eksperta $\mathrm{w}$ pomoc dla klienta $\mathrm{w}$ realizacji etapów 1 i 2 projektu wynosił około 10\% całkowitego budżetu usług realizacji projektu, jednak zainteresowanie wśród klientów nie było duże.

$\mathrm{Z}$ perspektywy klienta główne koszty transakcyjne związane $\mathrm{z}$ zawieraniem umów wynikały, dla etapu zarówno 2, jak i 3, z identyfikacji potrzeb funkcjonalnych wobec systemu oraz organizacji etapu 1 , tj. przetargu. $Z$ perspektywy dostawcy główne koszty transakcyjne związane z zawieraniem umów wynikały z organizacji procesu sprzedaży, tj. przygotowania prezentacji, oferty oraz negocjacji umowy. Na uwagę zasługuje fakt, iż obydwie strony wskazały, że na całkowity koszt transakcyjny zawarcia umowy wpływa w sposób znaczący opracowanie, uzgodnienie umowy dotyczącej realizacji usług wdrożeniowych etapów 2 i 3, szczególnie gdy jedna ze stron dąży do uzgodnienia umowy o charakterze kazuistycznym ${ }^{3}$. W trakcie pogłębionych warsztatów analitycznych reprezentanci zarówno dostawców, jak i klientów zgodnie stwierdzili, że umowy dotyczące realizacji etapów 2 i 3 powinny bardzo precyzyjnie definiować projekty, tzn. określić rezultaty, sposób realizacji, odpowiedzialność dwóch stron, lecz nie powinny mieć cech kazuistycznych, ponieważ w praktyce nie ma możliwości umieszczenia w umowie zapisów regulujących wszystkie zdarzenia, które mogą wystąpić w trakcie tak skomplikowanego projektu, jakim jest wdrożenie systemu informatycznego wspierającego zarządzanie. Z perspektywy klienta główne koszty transakcyjne związane z nadzorem realizacji umowy wynikają z zarządzania realizacją projektu oraz weryfikacją cząstkowych rezultatów

${ }^{3}$ Według Stownika wyrazów obcych [Stownik wyrazów... 1978] kazuistyka to sztuka stosowana zasad ogólnych do wypadków szczegółowych, metoda formułowania przepisów prawnych bazująca na przewidywaniu wypadków szczegółowych, zamiast ustalania zasad ogólnych; kazuistyczny - przesadnie drobiazgowy, dotyczący poszczególnych przypadków. 
zadań, które już zrealizowano. Z perspektywy dostawcy główne koszty transakcyjne związane z nadzorem realizacji umowy wynikają również z zarządzania realizacją projektu oraz dodatkowo z uzyskania weryfikacji rezultatów zadań przez klienta. Reprezentanci dostawców wskazali, że w stosowanych budżetach usług wdrożeniowych alokowali $10 \%$ całkowitego budżetu, co odpowiadało nakładom pracy związanej z zarządzaniem projektem. Również reprezentanci dostawcy wskazali, że klienci w sposób nieuzasadniony przedłużają weryfikację i akceptację rezultatów zrealizowanych projektów, co może powodować opóźnienia płatności wobec dostawców. Obydwie strony transakcji wskazały, iż na skalę kosztów transakcyjnych związanych z nadzorem nad realizacją umowy wpływają stałe analizy określające, czy $\mathrm{u}$ drugiej strony występują zachowania niepożądane, np. wynikający z oportunizmu hazard moralny. Z perspektywy zarówno klienta, jak i dostawcy koszty transakcyjne związane z dopasowaniem umowy do zmieniających się warunków wynikają z zarządzania zmianami w projekcie oraz identyfikacji i eliminacji czynników ryzyka. Z perspektywy klienta koszty transakcyjne związane z zakończeniem umowy głównie są efektem nakładów pracy związanych $\mathrm{z}$ odbiorem rezultatów końcowych lub cząstkowych prac projektowych na etapach 2 i 3 oraz ewentualnych kosztów rozwiązania konfliktów, które wynikają z niewłaściwego zrealizowania umów outsourcingowych. Z perspektywy dostawcy koszty transakcyjne związane z zakończeniem umowy wynikają z uzyskania finalnej weryfikacji projektu od klienta oraz z kosztów ekonomicznych i wizerunkowych ponoszonych w razie zrealizowania projektu w sposób właściwy.

Dodatkowe badania ankietowe wskazały najważniejsze czynniki wpływające na obniżenie kosztów transakcyjnych wybranej grupy przedsiębiorstw w Polsce, które zakończyły realizację etapów 1 i 2 i realizują etap 3 (uwzględniono perspektywę zarówno dostawcy, jak i klienta). Na rysunku 1 przedstawiono wyniki badań.

Zarówno klienci, jak i dostawcy wskazali, iż najważniejszym czynnikiem wpływającym na obniżenie poziomu kosztów transakcyjnych jest współpraca opierająca się na partnerstwie i zaufaniu. Istotnym czynnikiem jest współpraca zmniejszająca poziom zachowań oportunistycznych, tzw. moral hazard. Pogłębione warsztaty analityczne wśród wybranej grupy dostawców i klientów wykazały, że współpraca bazująca na partnerstwie i zaufaniu, w której występuje obniżony poziom zachowań oportunistycznych, obserwowana jest w przeważającej mierze wśród firm o kapitale zagranicznym, w szczególności pochodzących z Europy Zachodniej i USA. W firmach o kapitale polskim, które rozwinęły się w ostatnich 25 latach, rzadziej można dostrzec współpracę opierającą się na partnerstwie i zaufaniu. Według respondentów z tej grupy przedsiębiorstw, niestety, częściej mamy do czynienia z zachowaniami oportunistycznymi po stronie zarówno dostawcy, jak i klienta, sprzyjającymi zjawisku moral hazard w trakcie realizacji projektów informatycznych. Na uwagę zasługuje fakt, iż i dostawcy, i klienci dostrzegają jednak, iż ekspaci z USA lub Europy Zachodniej, pełniący funkcje zarządcze $\mathrm{w}$ firmach (od których zależy kultura organizacji) czasami w trakcie swojego pobytu w Polsce przejmują zachowania nie 


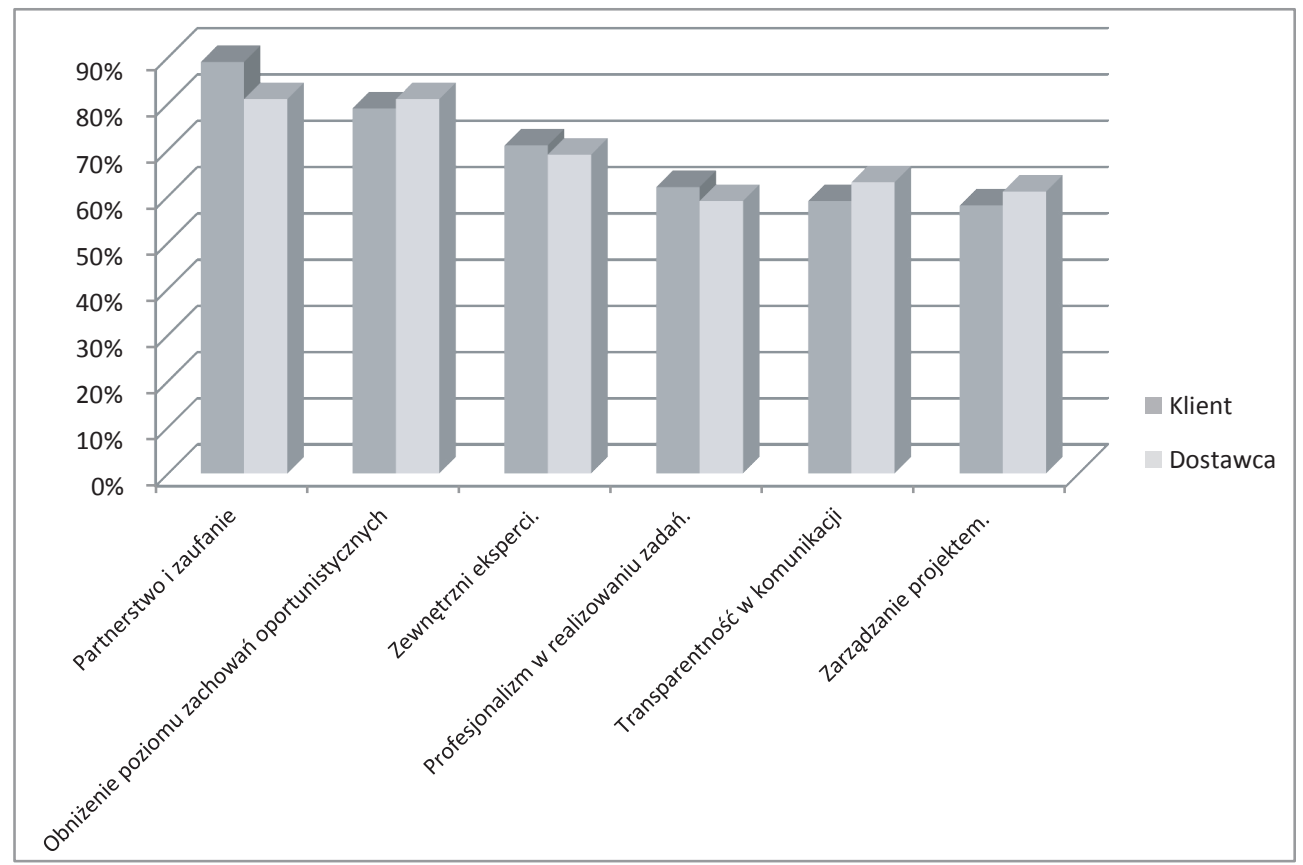

Rys. 1. Czynniki zmniejszające koszty transakcyjne w całym cyklu życia projektu i eksploatacji systemów informatycznych wspierających zarządzanie

Źródło: opracowanie własne.

sprzyjające partnerstwu i zaufaniu, co sprzyja wystąpieniu wspomnianego już zjawiska moral hazard. Dodatkowo na uwagę zasługuje zaangażowanie zewnętrznych ekspertów w roli mediatorów jako czynnika zmniejszającego koszty transakcyjne, mimo że wiąże się to z dodatkowymi kosztami projektowymi. Warsztaty analityczne wskazały, że zarówno bazująca na transparentności komunikacja w projekcie, jak i efektywne zarządzanie projektem stanowią istotne czynniki zmniejszające koszty transakcyjne w całym cyklu życia projektu i eksploatacji systemów informatycznych.

\section{Wnioski końcowe}

Przedstawione w artykule wybrane wyniki analiz materiału zebranego przez autora pozwalają na sformułowanie następujących, najważniejszych wniosków.

Po pierwsze, koszty transakcyjne dotyczą dwóch stron transakcji: zarówno klienta, jak i dostawcy, i są zdeterminowane różnymi czynnikami dla każdej z badanych grup. Odmienność uwarunkowań wynika z niezgodności interesów obu stron. Polega ona z jednej strony na maksymalizacji zysków dostawcy, tj. chęci wykonania projektu informatycznego opierającego się na stałym budżecie w ramach najmniej- 
szych kosztów, z drugiej strony na osiągnięciu przez klienta jego celów w ramach projektu w planowanym terminie i po minimalnych kosztach.

Po drugie, według przedstawionych w tab. 1 wyników badań przeprowadzonych przez autora w latach 2010-2014 wśród przedsięwzięć informatycznych zrealizowanych w Polsce średni współczynnik sukcesu wynosi $61 \%$, co oznacza, że średnio $39 \%$ przedsięwzięć informatycznych kończy się niepowodzeniem całkowitym lub częściowym. Wyniki badań jednoznacznie wskazały, że nieuzasadnione przekroczenie przez dostawce i odbiorcę kosztów transakcyjnych powyżej planowanych i akceptowalnych poziomów może być przyczyną zakończenia projektu niepowodzeniem całkowitym lub częściowym.

Po trzecie, koszty transakcyjne powinny być analizowane i szacowane na każdym z trzech etapów cyklu życia projektu. Respondenci wskazali, że analiza kosztów transakcyjnych odbywała się w trybie zarządzania ryzykiem projektowym, najczęściej indywidualnie, w grupie projektowej klienta i dostawcy. Dobrą i wskazaną praktyką jest zaangażowanie eksperta dziedzinowego, który może pomóc zmniejszyć m.in. koszty asymetrii informacji. Celem eksperta dziedzinowego, wykorzystującego swoją wiedzę teoretyczną i umiejętności dotyczące konkretnej grupy przedsięwzięć informatycznych, jest zminimalizowanie zagrożeń i pojawiających się czynników ryzyka. Badania pokazują jednak, że istnieje grupa klientów, którzy za wszelką cenę minimalizują koszt realizacji projektu informatycznego, czasami w sposób nieracjonalny. Nie dysponując dostateczną wiedzą i umiejętnościami, unikają angażowania ekspertów czy firm doradczych, mogących obniżyć poziom niepewności, niedoskonałości informacji oraz jej asymetrii głównie na etapach 1 i 2, pełniąc funkcję adwokata klienta. Według badań autora aktualnie koszt tego typu usług to $10-15 \%$ całkowitego kosztu usługi wdrożeniowej projektu. Dla kupującego system informatyczny ten dodatkowy koszt jest najczęściej zbyt wysoki. Wyniki badań pokazują, że jest to główna przyczyna tego, iż jedynie 7\% przedsiębiorstw decyduje się na zakup usług doradczych od firmy trzeciej - eksperta dziedzinowego, pozwalającego wesprzeć koordynację i zarządzanie projektami.

Po czwarte, badania wskazały, że najistotniejszymi czynnikami zmniejszającymi koszty transakcyjne w całym cyklu życia projektu i eksploatacji systemów informatycznych wspierających zarządzanie jest współpraca między dostawcą a odbiorcą bazująca na partnerstwie i zaufaniu oraz zmniejszająca poziom zachowań oportunistycznych, tzw. moral hazard. Badania dowiodły, że taka współpraca, podczas której występuje obniżony poziom zachowań oportunistycznych, obserwowany jest najczęściej wśród firm o kapitale zagranicznym, w szczególności pochodzących z Europy Zachodniej i USA. W firmach z kapitałem polskim rzadziej występuje współpraca opierająca się na partnerstwie i zaufaniu i, niestety, częściej mamy do czynienia z zachowaniami oportunistycznymi sprzyjającymi zjawisku moral hazard $\mathrm{w}$ trakcie realizacji projektów informatycznych.

Autor ma nadzieję, że przedstawione w publikacji wyniki badań pomogą osiągnąć dwa cele: wskażą specyfikę kosztów transakcyjnych podczas wdrażania przed- 
sięwzięć informatycznych oraz przyczynią się zwiększenia poziomu skuteczności w ich realizacji.

\section{Literatura}

Auksztol J., 2008, Outsourcing informatyczny $w$ teorii i praktyce zarzadzania, Wydawnictwo Uniwersytetu Gdańskiego.

Coase R.H., 1937, The nature of the firm, „Economica”, no. 4/16.

Dibbern J., Goles T., Hirscheim R., Jayatilak B., 2004, Information systems outsourcing: A survey and analysis of the literature, "The Data Base for Advance in Information Systems", no. 35/4.

Gregor S., 2006, The nature of theory in information systems, "MIS Quarterly", no. 30/3.

Lee J.N., Miranda S.M., Kim Y.M., 2004, IT Outsourcing strategies: Universalistic, contingency, and configutaional explanations of success, "Information Systems Research", no. 15/2.

Miranda S.M., Kim Y.M., 2006, Professional versus political contexts: Institutional mitigation and the transaction cost heuristic in information system outsourcing, "MIS Qurterly", no. 30/3.

Robins J.A., 1987, Organizational economics: Notes on the use of transaction cost theory, „Administration Science Quarterly", no. 32/1.

Słownik wyrazów obcych, 1978, PWN, Warszawa.

Wachnik B., 2015, Information Asymmetry in Four IT Project: The Client's Perspective. A Multiple Case Study, Information System Management, Wydawnictwo SGGW

Wachnik B., 2014, Reducing information asymmetry in IT projects, „Informatyka Ekonomiczna”, nr 1(31), Wydawnictwo Uniwersytetu Ekonomicznego we Wrocławiu, Wrocław.

Williamson E., 1979, Transaction-cost economics: The governance of contractual relations, „Journal of Law and Economics", no. 22/2. 